\title{
Receptor Activity-Modifying Protein 1
}

National Cancer Institute

\section{Source}

National Cancer Institute. Receptor Activity-Modifying Protein 1. NCI Thesaurus. Code C127138.

Receptor activity-modifying protein 1 (148 aa, $\sim 17 \mathrm{kDa}$ ) is encoded by the human RAMP1 gene. This protein is involved in the transport of calcitonin gene-related peptide type 1 receptor to the plasma membrane. 